\title{
A experiência democrática no Amazonas: a formação do PTB e a consolidação do Trabalhismo (1945/1964)
}

\section{The democratic experience in Amazonas: the formation of the PTB and the consolidation of Labor (1945/1964)}

\section{César Augusto Bubolz Queirós*}

Resumo: Este artigo tem o objetivo de compreender o processo de formação do Partido Trabalhista Brasileiro (PTB) no Amazonas e a consolidação da hegemonia trabalhista entre as décadas de 1950 e 1960, buscando analisar as disputas políticas que emergem após o processo de redemocratização no pós-45. O fortalecimento do PTB no estado se deu, sobretudo, a partir da eleição do advogado Plínio Ramos Coelho para o governo do estado do Amazonas em 1954, inaugurando um período de hegemonia trabalhista que teve continuidade com a eleição de Gilberto Mestrinho (1958) e, novamente, Plínio Coelho (1962), tendo se estendido até sua deposição, em junho de 1964. O processo de crescimento eleitoral do PTB ocorreu em um contexto marcado por uma série de enfrentamentos com o alvarismo, principal grupo representante do PSD no estado, disputas políticas e embates internos, que opuseram as principais lideranças trabalhistas do Amazonas.

Palavras-chave: Trabalhismo; Amazonas; política.

Abstract: This article aims to understand the formation process of the Brazilian Labor Party (PTB) in Amazonas and the consolidation of labor hegemony between the 1950s and 60s, seeking to analyze the political disputes that emerge after the post-45 re-democratization process. The strengthening of the PTB in the state occurred, above all, after the election of lawyer Plínio Ramos Coelho to the Amazonas state government in 1954, inaugurating a

Doutor em História pela Universidade Federal do Rio Grande do Sul (UFRGS). Professor do Departamento de História e do Programa de Pós-Graduação em História da Universidade Federal do Amazonas (UFAM). ORCID: https://orcid.org/0000-0002-5752-6148. E-mail: cesardequeiros@uol.com.br. 
period of labor hegemony that continued with the election of Gilberto Mestrinho (1958) and, again, Plinio Coelho (1962), having extended until its deposition, in June of 1964. The process of electoral growth of the PTB took place in a context marked by a series of confrontations with alvarismo, the main PSD representative group in the state, political disputes and internal clashes, which opposed the main labor leaders in Amazonas.

Keywords: Labor; Amazonas; Politics.

E STE ARTIGO TEM O OBJETIVo de compreender o processo de formação do Partido Trabalhista Brasileiro (PTB) no Amazonas e a consolidação da hegemonia trabalhista entre as décadas de 1950 e 1960 no estado, buscando analisar as disputas políticas que emergem após o processo de redemocratização no pós-45 e, com isso, contribuir com a historiografia sobre o tema ao colocar em evidência a trajetória de importantes lideranças trabalhistas que desempenharão um papel fundamental na política amazonense no decorrer das próximas décadas. O fortalecimento do PTB no estado se deu, sobretudo, a partir da eleição do advogado Plínio Ramos Coelho para o governo do Amazonas em 1954, inaugurando um período de hegemonia trabalhista que teve continuidade com a eleição de Gilberto Mestrinho (1958) e, novamente, Plínio Coelho (1962), tendo se estendido até sua deposição, em junho de $1964 .{ }^{1}$ O processo de crescimento eleitoral do PTB ocorreu em um contexto marcado pelo enfrentamento com o alvarismo, fenômeno político local caracterizado pela forte influência do ex-interventor Álvaro Maia na política estadual tendo como base partidária o PSD e seus aliados, e permeado por disputas políticas e embates internos que opuseram as principais lideranças trabalhistas do Amazonas. No entanto, antes de adentrar nas questões relacionadas às disputas e peculiaridades locais, buscaremos compreender alguns elementos relacionados ao trabalhismo e à formação do PTB nacional.

\section{O Trabalhismo no Brasil}

No ocAso do Estado Novo, foram criados os principais partidos políticos que atuaram durante a breve experiência democrática brasileira interrompida pelo golpe civil-militar de 1964 . Nesse contexto, no qual o governo enfrentava forte oposição e se intensificavam as pressões para a redemocratização do país, foi decretado o novo Código Eleitoral, Decreto n. 7.586, de maio de 1945, também chamado de Lei Agamenon, ${ }^{2}$ que regulamentava o alistamento eleitoral e as eleições, estabelecia o prazo para as novas eleições presidenciais, estaduais

1 QUEIRÓS, César Augusto Bubolz. O Trabalhismo de Plínio Ramos Coelho e o golpe de 1964 no Amazonas. Revista Mundos do Trabalho, Florianópolis, v. 8, n. 15, p. 49-65, 2016.

2 Em referência ao ministro da Justiça, Agamenon Magalhães. Interventor no estado de Pernambuco, fora convidado para ocupar o Ministério da Justiça em março de $1945 \mathrm{com}$ a finalidade de conduzir as reformas rumo a democracia. Sobre isso, ver: SOUZA, Maria do Carmo Campello de. Estado e partidos políticos no Brasil (1945-1964). $3^{a}$ ed., São Paulo: Alfa-Ômega, 1990. p. 111. 
e para a formação de uma Assembleia Constituinte, e normatizava a criação dos partidos políticos. Com isso, foram criados os partidos que assumiriam o protagonismo no cenário político brasileiro nas duas próximas décadas: ${ }^{3}$ a União Democrática Nacional (UDN), ${ }^{4} \mathrm{O}$ Partido Social Democrático (PSD) ${ }^{5}$ e o Partido Trabalhista Brasileiro (PTB). ${ }^{6}$ Para Fonseca, "a derrubada de Vargas pelos militares significou apenas vitória temporária de seus adversários. Os dois partidos por ele fundados, PSD e PTB, saíram fortalecidos da eleição, dominando a Câmara dos Deputados e o Senado"?

De fato, a criação do Partido Social Democrático (PSD) esteve diretamente relacionada à atuação dos interventores que, em nome de Vargas, reuniram prefeitos, membros da administração estadual e outros grupos de apoio ao governo, como proprietários rurais, industriais, comerciantes, funcionários públicos e outros. Interventores como Benedito Valadares (MG), Ernani Amaral Peixoto (RJ), ${ }^{8}$ Fernando Costa (SP), Agamenon Magalhães $(\mathrm{PE})^{9}$ e Álvaro Maia (AM) exerceram forte protagonismo na articulação das forças políticas e empresariais próximas de Getúlio Vargas. Nesse sentido, a criação do partido foi o resultado de uma convocação feita pelos interventores às bases municipais nos estados, resultando na fundação de um partido "de dentro para fora do Estado". ${ }^{10}$ Assim, passou a contar com uma ampla estrutura de sustentação, o que lhe permitia adaptar-se facilmente às exigências legais do processo eleitoral. Na convenção nacional de 17 de julho de 1945, foi lançada a candidatura de Eurico Gaspar Dutra à Presidência da República. Na mesma ocasião, foi formalizada a primeira comissão diretora, tendo Getúlio Vargas como presidente, Benedito Valadares (primeiro vice-presidente) e Fernando Costa (segundo vice-presidente). Álvaro Maia, interventor no estado do Amazonas, participou como membro do primeiro diretório nacional do partido e foi uma das principais lideranças do partido do estado. ${ }^{11}$

3 Aos três maiores partidos, agregaram-se o Partido Comunista Brasileiro (PCB), o Partido Social Progressista (PSP), o Partido Republicano (PR), o Partido Libertador (PL), o Partido Democrata Cristão (PDC), o Partido Republicano Progressista (PRP), o Partido Trabalhista Nacional (PTN), o Partido Social Trabalhista (PST), o Partido Republicano Trabalhista (PRT), o Partido Socialista Brasileiro (PSB) e o Movimento Trabalhista Renovador (MTR). HIPPOLITO, Lucia. Vargas e a gênese do sistema partidário brasileiro. Anos 90, Porto Alegre, v. 11, n. 19/20, p. 21-47, jan.-dez. 2004, p. 23.

4 Sobre a UDN, ver: BENEVIDES, Maria Victoria de Mesquita. A UDN e o udenismo: ambiguidades do liberalismo brasileiro (1945-1965). Rio de Janeiro: Paz e Terra, 1981.

5 HIPPOLITO, Lucia. De raposas e reformistas: o PSD e a experiência democrática brasileira (1945-64). Rio de Janeiro: Paz e Terra, 1985; D'ARAUJO, Maria Celina Soares. O segundo governo Vargas (19511954): democracia, partidos e crise política. Rio de Janeiro: Zahar, 1982. D’ARAUJO, Maria Celina Soares. Sindicatos, carisma e poder: o PTB de 1945-65. Rio de Janeiro: FGV, 1996.

6 Devemos destacar que, nessa conjuntura, o PCB passou por um breve período de legalidade, tendo apresentado o candidato Yedo Fiuza à Presidência da República e logrou o êxito de eleger um senador e 14 deputados federais. No entanto, teve seu registro cassado em 1947. Mesmo na clandestinidade, o partido terá uma importante atuação no período. PANDOLFI, Dulce. Camaradas e companheiros: história e memória do PCB. Rio de Janeiro: Relume Dumará, 1995.

7 FONSECA, Pedro Cezar Dutra. Vargas: o capitalismo em construção (1906-1954). $3^{a}$ ed., São Paulo: Hucitec, 2014, p. 330.

8 Ver: PANTOJA, Sílvia. As raízes do pessedismo fluminense (a política do interventor 1937-45). Rio de Janeiro: FGV/CPDOC, 1992.

9 Sobre Agamenon Magalhães, ver: PANDOLFI, Dulce. Pernambuco de Agamenon Magalhães: consolidação e crise de uma elite política. Recife: Editora Massangana, 1984.

10 SOUZA, Maria do Carmo Campello de. Estado e partidos políticos no Brasil (1945-1964). $3^{a}$ ed., São Paulo: Alfa-Ômega, 1990, p. 109.

11 Trataremos um pouco mais sobre Álvaro Maia no próximo tópico deste artigo. SANTOS, Eloína Monteiro. 
A fundação do Partido Trabalhista Brasileiro (PTB) também ocorreu sob a égide de Vargas: buscando criar um anteparo entre os trabalhadores e o Partido Comunista (que acabara de reingressar na legalidade), ${ }^{12}$ a criação do PTB estabeleceu uma aproximação com os operários urbanos e seus sindicatos. Assim, o PTB surge simultaneamente ao PSD como o resultado da frustração do projeto de reunir em um partido único as forças que apoiavam Vargas. Para Gomes, mesmo com as transformações políticas ocorridas ao final do Estado Novo, a tradição política de pouca legitimação dos partidos políticos e a ausência de uma mediação entre líderes e representados se mantiveram substancialmente inalteradas. Com isso, o apelo ao carisma pessoal de Vargas continua sendo uma constante, mesmo após 1945. No entanto, se o getulismo se caracteriza por essa profunda personalização, o trabalhismo acabou por ganhar diferentes lideranças, perfis relativamente independentes e especificidades regionais. Ademais, ao longo do tempo, seu ideário - que não se apresentava de modo substancialmente estruturado - foi sendo apropriado por diversas outras organizações que possuíam recortes próprios. ${ }^{13}$ O PTB surgia como o partido da classe trabalhadora e uma alternativa ao Partido Comunista, ora disputando espaços, ora construindo alianças. Caracterizava-se por uma grande ambivalência no aspecto ideológico e programático, facultando-lhe a possibilidade de realização de um amplo leque de alianças políticas.

Diferentemente do PSD, que desde cedo contou com a adesão das principais lideranças políticas dos estados e que possuíam clara vinculação ao Estado Novo e uma candidatura estruturada à presidência, o PTB surgiu sem grandes nomes da política nacional que pudessem impulsionar o partido. Daí a recorrente referência a Getúlio Vargas. Enquanto as candidaturas de Dutra (PSD) e Gomes estavam sendo articuladas, os trabalhistas apostavam na "Constituinte com Getúlio" e na realização de eleições diretas em que o então presidente pudesse concorrer. Nesse contexto, há uma clara vinculação entre trabalhismo e queremismo. Com a deposição de Vargas e a aproximação das eleições presidenciais, o PTB acabou formalizando seu apoio a Dutra e ao PTB. Em carta dirigida a Vargas, Napoleão de Alencar Guimarães sintetizava a situação do partido naquele contexto: "Não penso que nas presentes eleições o PTB seja bem-sucedido eleitoralmente. Mas, se se aliar ao PSD nas eleições estaduais, a experiência adquirida Ihe dará inquestionavelmente uma posição muitíssimo forte". ${ }^{14}$ Evidentemente esse acordo não transcorreu sem dissenções e controvérsias, mas

Álvaro Maia: uma liderança política cabocla. Manaus: EDUA, 1997.

12 Angela de Castro Gomes descarta essa hipótese ao afirmar que "pode-se descartar a hipótese de que a criação do PTB foi uma 'invenção de última hora', voltada especificamente para funcionar como um contrapeso à força crescente e surpreendente do Partido Comunista". GOMES, Angela de Castro. A invenção do Trabalhismo. $3^{a}$ ed., Rio de Janeiro: FGV, 2005. p. 282.

13 Entre eles estão o Partido Social Trabalhista (PST), organizado em 1947 no Rio de Janeiro como um desdobramento do Partido Proletário do Brasil (PPB); o Partido Trabalhista Nacional (PTN), fundado em 1945 por elementos diretamente vinculados ao Ministério do Trabalho, tinha como objetivo organizar a massa sindicalizada independente do PTB; o Partido Republicano Trabalhista (PRT), criado em 1948 para suceder ao Partido Republicano Democrático (PRD); o Partido Orientador Trabalhista (POT), fundado em 1945; e o Movimento Trabalhista Renovador (MTR), fruto de uma dissidência do PTB, foi fundado por Fernando Ferrari em 1960.

14 Angela de Castro Gomes descarta essa hipótese ao afirmar que "pode-se descartar a hipótese de que a criação do PTB foi uma 'invenção de última hora', voltada especificamente para funcionar como um contrapeso à força 
a vitória de Dutra foi garantida quando Vargas, às vésperas das eleições, declara seu apoio, tendo um enorme impacto nas urnas. ${ }^{15}$

O PTB saíra das eleições de 1946 com prestígio eleitoral consolidado e com uma participação crescente no eleitorado nacional. ${ }^{16}$ Embora não contasse com um esquema de sustentação em todo o país como conseguira o PSD, contava com a "mística getulista" e com o voto dos trabalhadores, mobilizado pelo próprio Ministério do Trabalho. ${ }^{17}$ Ademais, estava assentado em fortes bases sindicais, apresentando um cunho fortemente sindicalista. A maciça presença de sindicalistas nos quadros do partido e a canalização de esforços investidos durante o Estado Novo na organização sindical dos trabalhadores permitiram que o PTB se estabelecesse como o herdeiro das bandeiras do trabalhismo e do getulismo, estabelecendo-se com bases muito sólidas em estados como o Rio Grande do Sul e no Distrito Federal.

\section{O Trabalhismo no Amazonas}

COM O PROCESSO DE REDEMOCRATIZAÇÃo e a deposição do presidente, os dois partidos criados por Vargas passaram a ter forte representação no estado do Amazonas. Enquanto o PSD tinha como sua principal liderança Álvaro Maia, que havia sido interventor de Getúlio Vargas durante o Estado Novo, o PTB possuía algumas lideranças com um importante lastro político, como Vivaldo Palma Lima, e outras mais jovens, como Plínio Ramos Coelho. Em sua origem, PSD e PTB se aproximavam politicamente no estado uma vez que ambos reivindicavam o getulismo como sua principal bandeira.

Seguindo o exemplo dos demais estados, a criação do PSD no Amazonas esteve diretamente relacionada à influência política do interventor Álvaro Botelho Maia e à estrutura institucional já estabelecida, favorecendo a capilarização do partido não apenas na cidade de Manaus como também nos interiores do estado. Álvaro Maia reuniu prefeitos e outros membros da administração estadual e municipal, além de outros grupos de apoio ao governo, como proprietários rurais, industriais, comerciantes, funcionários públicos e outros. Para Eloína Santos, Álvaro Maia tinha sua sustentação política nas "classes conservadoras amazonenses", setores tradicionais da economia ligados ao comércio e ao extrativismo e que enfrentavam a crise crônica dos preços da borracha natural e agravada pelas dificuldades econômicas do estado. ${ }^{18}$ Com a "Revolução" de 30 e a renúncia do governador Dorval Pires

crescente e surpreendente do Partido Comunista". GOMES, Angela de Castro. A invenção do Trabalhismo. $3^{\mathrm{a}}$ ed., Rio de Janeiro: FGV, 2005. p. 282.

15 Protásio Vargas, irmão de Getúlio, afirmara que "Todos sabemos, os teus amigos, que votar no Dutra [...] é o mesmo que tomar um purgante. É necessário fazê-lo, ainda que repugnante". GOMES, Angela de Castro. A invenção do Trabalhismo. $3^{a}$ ed., Rio de Janeiro: FGV, 2005. p. 292.

16 GOMES Angela e D'ARAÚJO, Maria C. Getulismo e Trabalhismo. Rio de Janeiro: Ática, 1989. p. 36.

17 Angela de Castro Gomes descarta essa hipótese ao afirmar que "pode-se descartar a hipótese de que a criação do PTB foi uma 'invenção de última hora', voltada especificamente para funcionar como um contrapeso à força crescente e surpreendente do Partido Comunista". GOMES, Angela de Castro. A invenção do Trabalhismo. $3^{a}$ ed., Rio de Janeiro: FGV, 2005. p. 282.

18 SANTOS, Eloína. Álvaro Maia: uma liderança política cabocla. EDUA: Manaus, 1997. p. 82. 
Porto, Juarez Távora indicou Álvaro Maia para a interventoria do estado, tendo ficado no cargo de 20 de novembro de 1930 a agosto de 1931, quando exonerou-se do cargo e retirou-se provisoriamente da atividade política. Em maio de 1933, Álvaro Maia foi eleito um dos quatro integrantes da bancada amazonense à Assembleia Nacional Constituinte e, no início de 1935, foi eleito senador e, em seguida, governador do Amazonas pela Assembleia Constituinte Estadual, passando a ocupar o cargo de interventor após o golpe do Estado Novo. Com a queda de Getúlio Vargas, em outubro de 1945, Maia é substituído no governo estadual por Emiliano Estanislau Afonso, tendo sido eleito senador constituinte pelo PSD.

A criação do PSD no estado apoiou-se fortemente no prestígio adquirido por Álvaro Maia ao longo do período em que esteve no comando do executivo estadual e em sua relação com as bases municipais, passando a contar com uma ampla estrutura de sustentação junto às elites políticas e econômicas do estado. Para concretizar a tarefa de organização do partido no estado, Álvaro Maia contou com a colaboração de algumas das principais lideranças políticas locais, como Rui Araújo, Valdemar Pedrosa e Leopoldo Peres. Para Eloína Santos, houve um forte elemento de continuidade entre o fim do regime autoritário e o início do período de democratização no estado do Amazonas em virtude da liderança de Álvaro Maia, não tendo havido o desmantelamento da máquina política e nem ocorreram mudanças significativas nos grupos políticos dominantes. ${ }^{19}$ No entanto, as décadas seguintes trariam consigo o inexorável declínio político do alvarismo e a ascensão de novas lideranças que traziam em sua formação política o germe do trabalhismo.

No Amazonas, a criação do diretório estadual do Partido Trabalhista Brasileiro teria ocorrido no dia 14 de julho de 1945, tendo como signatários Manoel Dias Anunciação (presidente), Olindo Salles Neto (secretário), Bolívar Pereira Melo (tesoureiro), Amadeu de Castro, Serafim Augusto de Andrade, Almerindo Pantoja, Luís Catete Gonçalves, Vitor Veloso, Manoel Romão, Aurélio Lago, Sebastião de Oliveira Rego, Abílio Emiliano dos Santos, Antônio Vasconcelos e Raimundo Pinheiro Bastos. ${ }^{20}$

Com a organização da Frente Democrática Getúlio Vargas (FDGV), que tinha a finalidade de prestar solidariedade a Getúlio Vargas em meio à crise institucional que se avolumava, a estruturação do Partido Trabalhista Brasileiro teve significativo impulso. ${ }^{21} \mathrm{Em}$ agosto, a FDGV organizou um comício no largo São Sebastião durante o qual foi divulgado um Manifesto à Nação Brasileira, lançando a candidatura de Getúlio Vargas à disputa pela presidência, dirigindo um "apelo patriótico" para que Vargas aceitasse o registro da candidatura uma vez que nenhum outro candidato seria capaz de satisfazer as aspirações do povo e das classes trabalhadoras. ${ }^{22}$ Entre os organizadores do ato estavam Vivaldo de Palma Lima e Plínio Ramos Coelho. Participavam ainda da frente nomes como Renato

19 SANTOS, Eloína. Álvaro Maia: uma liderança política cabocla. EDUA: Manaus, 1997. p. 128.

20 Jornal do Commercio, Manaus, p. 4, 25 set. 1945.

21 Jornal do Commercio, Manaus, p. 1, 25 ago. 1945.

22 Jornal do Commercio, Manaus, p. 1, 29 ago. 1945. 
Bessa, Francisco Pereira, Kideniro Teixeira, Áureo Melo, Medeiros Costa, Octávio Câmara, Luiz Maia e Walter Oliveira.

No dia 19 de setembro, a FDGV realizou uma reunião na sede da União Operária Amazonense com a presença dos "presidentes de sindicatos de classe e seus associados e, em geral, todos os trabalhadores manuais e intelectuais" a fim de se proceder a escolha do diretório provisório do Partido Trabalhista Brasileiro no estado. ${ }^{23}$ A reunião foi convocada por Vivaldo Palma Lima e acabou gerando uma disputa em torno da legitimidade da representação do PTB no estado e um conflito com a diretoria criada no mês de julho. Essa diretoria publicou na imprensa uma nota aos trabalhadores na qual denunciava a criação de "uma segunda diretoria do mesmo partido" organizada por Vivaldo Palma Lima e encaminhou um veemente protesto à Comissão Executiva Central do partido a fim de que fossem tomadas providências. ${ }^{24}$ Não conseguimos identificar a resposta da Comissão Executiva nacional mas a solução encontrada foi a realização de uma reunião ocorrida no dia 17 de outubro, na sede do Sindicato dos Taifeiros, que contou com a presença do delegado regional do Ministério do Trabalho Eduardo Levy, na qual se resolveu o imbróglio com a "aclamação definitiva" da nova diretoria do partido. A nova diretoria era composta pelo jornalista Aristophano Anthony (presidente), Francisco Caetano (vice-presidente), Oseas Martins (primeiro-secretário), Plínio Ramos Coelho (segundo-secretário), Octávio Câmara (primeiro-tesoureiro) e Almerindo Mendes Pantoja (segundo-tesoureiro). Ao que parece, nessa reunião as disputas entre os dois grupos foram resolvidas e a nova diretoria integrou membros da FDGV (Plínio Ramos Coelho) e membros da primeira diretoria (Almerindo Mendes Pantoja) e a reunião contou tanto com a presença do fundador do primeiro diretório do PTB no Amazonas, o presidente do Sindicato dos Portuários Manuel Elias de Almeida Anunciação, quanto de Vivaldo Palma Lima, liderança da FDGV e responsável por convocar a reunião de setembro que iria eleger um novo diretório. ${ }^{25}$

Vivaldo de Palma Lima foi uma das principais lideranças do PTB no estado, tendo sido eleito deputado federal em 1947, mas falecido durante o mandato (1949). Foi um dos fundadores do Partido Trabalhista Amazonense, partido criado em 1933 e que possuía forte relação com o movimento sindical no estado e com Getúlio Vargas no plano nacional. Foi editor do jornal Tribuna Popular, periódico do Partido Trabalhista Amazonense (PTA) ${ }^{26}$ que era um "instrumento de orientação e propagação do ideário Trabalhista" no Amazonas. ${ }^{27}$ Sobre

23 Jornal do Commercio, Manaus, p. 1, 29 ago. 1945.

24 Jornal do Commercio, Manaus, p. 1, 19 set. 1945.

25 Jornal do Commercio, Manaus, p. 6, 18 out. 1945.

26 O Partido Trabalhista Amazonense (PTA) foi criado em 1933 e se autoproclamava "o legítimo representante dos anseios da classe trabalhadora". Luís Tirelli foi uma de suas principais lideranças. PIO Jr., Amaury Oliveira. O Trabalhismo no Amazonas: o periódico Tribuna Popular como instrumento de "orientação das hostes trabalhistas". Dissertação (Mestrado em História) - Instituto de Ciências Humanas e Letras, Universidade Federal do Amazonas, Manaus, 2015, p. 105.

27 Vivaldo de Palma Lima nasceu em 1877, em Salvador, onde concluiu seus estudos em Medicina, Farmácia e Odontologia, tendo vindo para a capital amazonense após ter sido nomeado agente federal de saúde. Em 1917, contribuiu para a fundação do Instituto Geográfico e Histórico do Amazonas (IGHA). Foi um dos fundadores do Partido Trabalhista do Amazonas, partido criado em 1933, com forte relação com o movimento 
esse periódico, Pio Jr. afirma que o jornal passa a ser destinado à "orientação das hostes trabalhistas" e, portanto, "buscava incentivar o alistamento eleitoral e a participação política de seus filiados e simpatizantes, para quem o não alistamento eleitoral representaria uma 'indiferença criminosa'". ${ }^{28}$ Por meio do periódico, o PTA dirigia-se às associações para propalar as vantagens da adesão dos sindicatos ao MTIC. Segundo Pio Jr., a "chegada a Manaus das Cartas Sindicais - documento em que o MITC oficializava a adesão do sindicato - por vezes não era somente anunciada [pelo periódico], mas transformada em um momento festivo, que servia para promover as lideranças do PTA, principalmente entre seus correligionários e simpatizantes". ${ }^{29}$ Seu filho, Vivaldo Palma Lima Filho, foi presidente do Diretório Estadual do PTB e se elegeu senador por duas legislaturas (1950-1958 e 1958-1966).

Uma das jovens lideranças do PTB no estado era o advogado Plínio Ramos Coelho. ${ }^{30}$ Nascido na cidade de Humaitá (AM), em 21 de fevereiro de 1920, estudou no Colégio Dom Bosco e bacharelou-se pela Faculdade de Direito do Amazonas, tendo sido professor da Faculdade de Ciências Econômicas e da Faculdade de Direito do Amazonas. ${ }^{31}$ Em 1944, Plínio Coelho assumiu a vice-presidência do Diretório Acadêmico da Faculdade de Direito da Universidade do Estado do Amazonas que na ocasião era presidido por Agnelo Bittencourt Filho. Como advogado, Plínio Coelho atuava ativamente junto aos sindicatos dos trabalhadores marítimos, dos gráficos e dos portuários. A histórica atuação de Vivaldo Palma Lima entre os trabalhadores desde os tempos de PTA e a atuação do jovem Plínio Ramos Coelho como advogado desses sindicatos reforçavam o elo do PTB com os trabalhadores e fortalecia o vínculo com essas bases eleitorais.

Em janeiro de 1947, foram realizadas eleições gerais para os estados. ${ }^{32}$ Contrariando a orientação nacional de coligar com o PSD, o PTB amazonense se coligou localmente com a UDN e com o PCB, uma aliança esdrúxula que tinha o objetivo de derrotar o PSD de Álvaro Maia, que ainda dominava a cena política naquele período, tendo eleito dois senadores constituintes e três deputados na eleição ocorrida em fins de $1945 .^{33}$

sindical no estado. Mais tarde, vai se tornar uma das principais lideranças do Partido Trabalhista Brasileiro, tendo sido eleito deputado federal por esta sigla. PIO Jr., Amaury Oliveira. O Trabalhismo no Amazonas: o periódico Tribuna Popular como instrumento de "orientação das hostes trabalhistas". Dissertação (Mestrado em História) - Instituto de Ciências Humanas e Letras, Universidade Federal do Amazonas, Manaus, 2015.

28 PIO Jr., op. cit., 2015, p. 99.

29 PIO Jr., op. cit., 2015, p. 101.

30 Sobre Plínio Ramos Coelho, ver: QUEIRÓS, César Augusto Bubolz. Plínio Ramos Coelho: o ganso do Capitólio. In: QUEIRÓS, César Augusto B. e UGARTE, Auxiliomar (org.). Trajetórias políticas na Amazônia republicana. Manaus: Editora Valer, 2019.

31 DINIZ, Almir. Imortais do Amazonas: dicionário biográfico. Manaus: Uirapuru, 2002. p. 162.

32 A eleição realizou-se no primeiro domingo após 120 dias contados da promulgação da Constituição dos Estados Unidos do Brasil pela Assembleia Nacional Constituinte - ocorrida em 18 de setembro de 1946. $\mathrm{Na}$ ocasião, realizaram-se as primeiras eleições diretas para governadores e deputados que comporiam a Assembleia Constituinte e para os cargos de terceiro senador e seu suplente (mandato de quatro anos); suplentes dos senadores eleitos em 1945 (mandato de oito anos); e deputados federais (para completar as bancadas estaduais).

33 Os senadores eleitos para a Assembleia Constituinte foram Álvaro Botelho Maia e Valdemar Pedrosa, ambos do PSD. Na mesma eleição, foram escolhidos cinco deputados constituintes: Cosme Alves Ferreira F., Leopoldo Peres e Francisco Pereira da Silva, todos do PSD, além de Leopoldo Neves (PTB) e Manuel Severiano Nunes (UDN). 
Para governador, o vitorioso foi Leopoldo Amorim da Silva Neves (PTB), ${ }^{34}$ tendo superado o candidato do PSD, Rui Araújo, que havia sido secretário-geral de Álvaro Maia durante o Estado Novo. Na mesma ocasião, Manoel Severiano Nunes (UDN) foi eleito para o Senado e abriu espaço para a posse dos suplentes Manuel Anunciação e Alexandre Carvalho Leal na Câmara Federal. A fim de completar a bancada federal do estado, foram eleitos mais dois deputados federais: Antovilla Rodrigues Mourão Vieira (UDN) e Vivaldo Lima (PTB). Dos trinta deputados estaduais eleitos, quinze ficaram com a UDN, nove com o PSD, cinco com o PTB ${ }^{35}$ e um com o PTN. A coligação UDN/PTB elegeu dois terços da bancada estadual. O resultado das eleições gerais de 1947 foi amplamente desfavorável ao PSD que, mesmo com a forte influência do então senador Álvaro Maia, não conseguiu um resultado satisfatório nas urnas. Nessa eleição, algumas das principais lideranças estaduais do PTB já começavam a aparecer no cenário político.

No entanto, a vitória de Leopoldo Neves foi contestada na Justiça Eleitoral por seus adversários políticos: entre fevereiro e maio, o governo foi exercido por João Nogueira da Mata, presidente do Conselho Administrativo do estado, mas, após obter ganho de causa, Leopoldo Neves deixou a Câmara e foi empossado na chefia do governo. ${ }^{36}$ Neves não chegou ao término de seu mandato: seis meses antes, se desincompatibilizou do cargo com o intuito de concorrer ao Senado. O resultado dessa eleição acabou por acarretar diversas dificuldades para o governador petebista, uma vez que a UDN conseguiu dominar a Assembleia Legislativa Estadual elegendo quinze deputados, enquanto o PTB possuía apenas cinco. ${ }^{37}$

Nas eleições de 1950, o PTB estadual voltou a se aproximar do PSD, formando uma coalizão denominada Frente Libertadora (PSD, PTB, PDC). A aliança entre PTB e PSD, reaproximando alvarismo e trabalhismo, contou com o envolvimento pessoal de Getúlio Vargas e elegeu Álvaro Botelho Maia ${ }^{38}$ para o governo do estado, tendo vencido Manoel Severiano Nunes (UDN). No entanto, a aliança com o PSD não trouxe ao PTB os esperados frutos eleitorais: embora tenha eleito um senador - Vivaldo Palma Lima F. ${ }^{039}$ - e um deputado federal - Plínio Ramos Coelho -, a bancada estadual caiu de cinco para quatro parlamentares ${ }^{40}$ enquanto que o PSD teve um crescimento de nove para doze cadeiras. Com isso, Plínio Coelho, que se tornara a mais destacada liderança do partido no estado, não tardara a romper a aliança com Maia, assumindo a liderança da oposição e tornando-se o mais duro crítico do alvarismo. ${ }^{41}$

34 Leopoldo Neves nasceu em Manaus, em 1898, tendo morrido em novembro de 1953. Leopoldo Neves havia sido eleito deputado pelo Amazonas à Assembleia Nacional Constituinte na legenda do Partido Trabalhista Brasileiro (PTB), participando dos trabalhos constituintes. Dicionário Biográfico Amazonense, 317/320.

35 Os deputados estaduais eleitos pelo PTB foram Áureo Bringel de Mello, Plínio Ramos Coelho, José Carlos Nobre da Silva, Aristophano Anthony e Alfredo Eulipes Jackson Cabral.

36 CPDOC/FGV.

37 SANTOS, Eloína. Uma liderança política cabocla: Álvaro Maia. Manaus: EDUA, 1997. p. 131.

38 Sobre Álvaro Maia, ver: SANTOS, Eloína. Uma liderança política cabocla: Álvaro Maia. Manaus: EDUA, 1997.

39 Seu pai, Vivaldo Palma Lima, faleceu em meio a seu mandato, em 1949.

40 Os deputados estaduais eleitos pelo PTB foram Áureo Bringel de Mello, Alfredo Eulipes Jackson Cabral, Túlio Azevedo e Tércio Araújo da Silva. Banco de dados do Tribunal Superior Eleitoral.

41 GARCIA, Etelvina. Manaus, referências da história. Manaus: Norma Editora, 2012. p. 101-102. 
Diante do resultado eleitoral insatisfatório, as lideranças trabalhistas do estado, sob a orientação de Getúlio Vargas, iniciaram o desafio de articular o partido no interior do Amazonas. Segundo Angela de Castro Gomes,

Tornar o PTB um partido eleitoralmente bem-sucedido exigiria uma série de tarefas árduas, que poderiam analiticamente ser apresentadas como integrando duas dimensões fundamentais. A primeira dimensão era a organizacional e exigia a reestruturação com a expansão da máquina do partido, com destaque para sua penetração em vários estados da Federação, incluindo os municípios rurais. ${ }^{42}$

Se essa dificuldade organizacional era sentida pelos estados onde o PTB estava mais organizado - como RS e SP -, no Amazonas essa seria uma tarefa particularmente complicada. Em um relatório encaminhado em 1951 ao presidente Getúlio Dornelles Vargas, avaliando os resultados eleitorais e os problemas políticos do estado, Plínio Coelho salientou que, dos 24 municípios - excluindo a capital, cujo prefeito é nomeado - o PTB conseguira eleger apenas dois prefeitos - Manicoré e Tefé. Tal situação se deve, segundo Plínio, "à guerra fria movida pela família Cidade, dirigida pelo coletor federal Alarico Cidade, os prefeitos e nossos vereadores passaram para o PSD. Tefé continuou sendo bastião nosso: é $60 \%$ trabalhista". ${ }^{43}$

Plínio prossegue na análise da situação do PTB no estado e informa que:

Estamos presentemente com diretórios em 10 comunas, reestruturados. São as principais do estado. Em Manicoré, Benjamin Constant, Eirunepé e Tefé os ataques e prisões se sucedem contra os nossos elementos, através de delegados de polícia, nomeados entre os cabos eleitorais do PSD.

Em todos esses municípios só temos um adversário: o dr. Álvaro Maia, que personifica, no Amazonas, o PSD. Todos os atos praticados são por ele inspirados, embora jamais tenha deixado de declarar que não concorda com perseguições. Enquanto, porém, poupa a udenistas, transfere e persegue petebistas, não nomeando, ao menos, o delegado de polícia a pedido nosso - e há cinco meses pedimos - para o único município onde somos maioria: Tefé. ${ }^{44}$

As dificuldades em estruturar os diretórios estaduais passavam, entre outras coisas, pelas perseguições políticas promovidas pelos partidários do governador Álvaro Maia. Com isso, os esforços de organização partidária eram dificultados pela forte presença do PSD no interior. Da mesma forma, na análise de Plínio Coelho, havia uma comunhão de interesses entre o PSD e a UDN, sobretudo em função de que a maioria dos seringalistas pertencia a esses dois partidos. Para Plínio,

os seringalistas são, na sua totalidade, udenistas, pessedistas e pessepistas, sendo a maioria filiada aos dois primeiros credos políticos. É de ver-se e sentir-se, destarte, o azedume e a má vontade que buscam emprestar ao comportamento de V. Ex.a. Respondi que Presidente algum já fizera mais

42 GOMES, Angela de Castro. Trabalhismo e Ideologia. In: GOMES, Angela de Castro. A Crise dos anos 50. p. 136.

43 Relatório de Plínio Ramos Coelho a Getúlio Vargas expondo os problemas políticos e socioeconômicos do estado do Amazonas e propondo medidas para o fortalecimento do PTB na região. Em anexo, recorte do "O Jornal", de Manaus, transcrevendo nota oficial da Ordem dos Advogados do Brasil, seção do Amazonas. Rio de Janeiro. 23 out. 1951.

44 Relatório de Plínio Ramos Coelho a Getúlio Vargas. Arquivo Getúlio Vargas. FGV/CPDOC. 23 out. 1951. 
pela Amazônia do que o atual Presidente e que planejamento de valorização da Amazônia, esquecida de 1946 a 1950, era uma resposta cabal aos maldizentes de sempre, aos pescadores de águas turvas. ${ }^{45}$

Ao observar que os seringalistas seriam os próceres do PSD e da UDN, o então deputado federal alertava para a crise financeira que assolava o estado e pedia apoio do presidente a um projeto que multaria os seringalistas que, em seus seringais, não exercessem atividades agropecuárias. Para ele,

O comércio acha-se asfixiado, Sr. Presidente. Não só porque a miséria varre o Amazonas, como também porque os seringalistas, à espera do aumento do preço, não descem a borracha. É fácil compreender o significado dessa retenção e seus desastrosos efeitos. Pedimos, porém, que seja favorável: único meio de se obter aumento da produção. ${ }^{46}$

Devemos observar que, no início dos anos 50, a redução do interesse externo pela goma elástica não foi compensada pelo aumento do consumo interno diante do crescimento de uma indústria nacional embrionária. Todavia, mantinha-se a esperança na possibilidade de reabilitação econômica da borracha em face de seu emprego crescente na elaboração de artefatos e insumos. Ademais, insistia-se na aplicação de recursos advindos de projetos federais de incentivos fiscais, quase todos direcionados naquele momento ao estado vizinho do Pará. ${ }^{47}$

Ao término do relatório, Plínio Ramos Coelho faz algumas sugestões ao presidente Getúlio Vargas. Em primeiro lugar, recomendava a transferência do coletor federal Alarico Justino Cidade para Eirunepé ou outro município com o argumento de que "violência gera violência" e que, com sua transferência, "não estaremos plantando vento, estaremos distribuindo tempestade, mas em legítima defesa, em revide". ${ }^{48}$ Cidade e sua família eram acusados de perseguirem os membros do PTB em Manicoré. Getúlio Vargas acatou a sugestão de Plínio Coelho e decretou sua remoção de Manicoré para Einurepé, acarretando uma grande insatisfação por parte do PSD e de Álvaro Maia, que encaminhou um telegrama ao Palácio do Catete solicitando a manutenção do funcionário, alegando que o mesmo tratava-se de funcionário exemplar e chefe de numerosa família, negando que houvesse perseguição por motivos políticos. ${ }^{49}$

Em segundo lugar, Coelho observou que as direções do lapetec, IAPI, IAM e Ipase estavam todas sob o controle do PSD e do PSP, o que representava um "diuturno enfraquecimento da política trabalhista", sugerindo que o presidente nomeasse diretorias ligadas ao PTB. Em terceiro lugar, propôs a nomeação de um trabalhista para o Fomento Federal, órgão responsável por distribuir as sementes e que poderia fazer algo pelo homem do interior. Plínio destaca que "o atual titular é pessedista de quatro costados". ${ }^{50} \mathrm{Em}$ quarto

45 Relatório de Plínio Ramos Coelho a Getúlio Vargas. Arquivo Getúlio Vargas. FGV/CPDOC. 23 out. 1951. 46 Relatório de Plínio Ramos Coelho a Getúlio Vargas. Arquivo Getúlio Vargas. FGV/CPDOC. 23 out. 1951.

47 Sobre isso, ver: SILVA, José Lopes. Amazonas: do extrativismo à industrialização. Manaus: Valer, 2011. p. 394.

48 Relatório de Plínio Ramos Coelho a Getúlio Vargas. Arquivo Getúlio Vargas. FGV/CPDOC. 23 out. 1951.

49 Telegrama Álvaro Maia. Documentos sobre a remoção de Alarico Cidade. Arquivo Getúlio Vargas. FGV/ CPDOC. 11 nov. 1951.

50 Relatório de Plínio Ramos Coelho a Getúlio Vargas. Arquivo Getúlio Vargas. FGV/CPDOC. 23 out. 1951. 
lugar, solicitava a nomeação de um trabalhista para a Colônia Agrícola Nacional do Amazonas que, segundo ele, "representa um grande eleitorado e está sob o domínio e propaganda do PSD". ${ }^{51}$ Plínio encerra afirmando que "com atos assim, o PTB teria todas as probabilidades de ser vitorioso nas eleições. Seria uma demonstração irrecorrível de apoio, de solidariedade de V. Ex.a à causa trabalhista". ${ }^{2}$

Se o PSD de Álvaro Maia era apresentado como o grande obstáculo para o crescimento eleitoral do PTB, o PCB era visto como uma ameaça menor, um partido que "nunca, em tempo algum, logrou fazer, em Manaus ou no estado, ao menos um vereador, o que diz perfeitamente de sua inexpressividade". ${ }^{53}$

A forte atuação do PTB - e, em especial, de algumas lideranças do partido - junto aos sindicatos do estado também pode ser claramente observada. Como deputado federal, Plínio Coelho atuou em defesa dos trabalhadores do porto de Manaus, intercedendo junto ao governo federal a fim de que fosse aprovado aumento salarial para a categoria. Em março de 1953, Plínio Coelho recebeu um telegrama de Lourival Fontes - secretário da Presidência da República - informando que a questão do aumento salarial dos trabalhadores do porto de Manaus havia sido aprovada em favor dos portuários. ${ }^{54}$ Anexo ao telegrama, encontramos uma carta endereçada ao presidente Getúlio Vargas na qual se queixava de não poder "cumprir a orientação partidária de, com urgência, percorrer todo o estado, visando à reestruturação dos diretórios existentes e criação de novos". O então deputado justificava o fato de não ter atendido a orientação partidária da seguinte maneira:

"É que, até aqui, a questão do aumento dos salários referentes aos trabalhadores do porto de Manaus NÃO FOI RESOLVIDA. Com esta, já três vezes pedi a interferência de V. Ex.a a fim de evitar a GREVE. SOS, Presidente". ${ }^{5}$

Resolvida a questão do aumento dos salários dos trabalhadores do porto de Manaus, Plínio Coelho e Leopoldo Cunha Mello passaram a percorrer as cidades do interior do Amazonas - Itacoatiara, Parintins, Itapiranga, Maués, Borba - em função do lançamento de suas candidaturas na convenção do PTB realizada em 22 de maio de $1954 .{ }^{56}$

Gradativamente, o PTB se organizava no estado por meio da ação pessoal de Getúlio Vargas que, aos poucos, ia movimentando as peças no tabuleiro amazonense, fortalecendo lideranças e afastando antigos aliados.

Nas eleições de outubro de 1954, o PTB colheria os frutos desse trabalho de organização da estrutura partidária nos municípios de construção de lideranças políticas associadas à figura de Vargas. Com isso, Plínio Ramos Coelho se elegeu governador do estado pelo

51 Relatório de Plínio Ramos Coelho a Getúlio Vargas. Arquivo Getúlio Vargas. FGV/CPDOC. 23 out. 1951.

52 Relatório de Plínio Ramos Coelho a Getúlio Vargas. Arquivo Getúlio Vargas. FGV/CPDOC. 23 out. 1951.

53 Relatório de Plínio Ramos Coelho a Getúlio Vargas. Arquivo Getúlio Vargas. FGV/CPDOC. 23 out. 1951.

54 Telegrama de Lourival Fontes a Plínio Coelho. Arquivo Getúlio Vargas. CPDOC/FGV. 21 mar. 1953.

55 Carta anexa ao Telegrama de Lourival Fontes a Plínio Coelho. Arquivo Getúlio Vargas. CPDOC. 21 mar. 1953.

56 Telegrama de Leopoldo Cunha e Plínio Coelho a Getúlio Vargas. Arquivo Getúlio Vargas. CPDOC/FGV. 7 jun. 1954 
PTB, derrotando Rui Araújo, candidato da coligação formada pela UDN, PSD, PDC e PTN, e selando a derrota de Álvaro Maia. Essa eleição, vencida por Plínio por apertada margem de votos, colocou em lados opostos as forças políticas que se formaram e consolidaram durante o Estado Novo - tendo em Álvaro Maia seu principal expoente - e o trabalhismo representado pela ousadia de Plínio Coelho, um dos mais jovens governadores do país (tinha apenas 34 anos). Candidato ao Senado pelo PSD, Álvaro Maia não conseguiu se eleger, embora duas cadeiras estivessem em disputa (conquistadas por Leopoldo Cunha Mello e Antovilla Rodrigues Mourão Vieira, ambos do PTB). Para Eloína Santos, a vitória de Plínio Coelho evidencia o crescimento político do PTB, que ganhava forças desde 1946, e marca o afastamento do poder do PSD e da liderança de Álvaro Maia, que ainda tentara por duas vezes retornar à atividade política (em 1958 e 1962), só conseguindo ser nomeado senador pela Arena após o golpe de 1964, vindo a falecer durante o mandato. ${ }^{57}$

Segundo Etelvina Garcia, a eleição de Plínio Coelho representava o rompimento da estrutura de poder que se consolidara no Amazonas a partir de $1930 \mathrm{com}$ a liderança de Álvaro Maia. ${ }^{58} \mathrm{O}$ grau de tensão gerado por tal ruptura do sistema de forças políticas no estado pode ser percebido se observarmos as precauções verificadas a partir do acionamento das forças públicas no sentido de garantir a posse do novo governador: o vespertino $A$ Tarde, a pedido do gabinete do governador em exercício, deputado Perseverando da Trindade Garcia, publicara que

(...) de ordem do Exmo. Sr. Presidente da República dos Estados Unidos do Brasil, a partir de 0 hora do dia 29 do corrente a guarda do Palácio Rio Negro e a manutenção da ordem pública nesta capital ficarão sob as ordens do Exmo. Sr. Cel. Comte. da Guarnição Federal do Amazonas. ${ }^{59}$

Na mesma edição do jornal, em nota do Comando da Guarnição Federal do Amazonas, afirmava-se que "[...] em cumprimento a uma ordem do Exmo. Sr. Presidente da República, a guarda do Palácio Rio Negro e a manutenção da ordem pública desta capital ficarão a cargo do Comte. da Guarnição Federal do Amazonas, a partir de 0 hora do dia 29 de janeiro de $1955 " .60$

A posse do novo governador e a perspectiva de consolidação do projeto político dos trabalhistas ${ }^{61}$ provocavam grande receio entre as elites locais: a proximidade histórica dos trabalhistas com o meio sindical ameaçava a manutenção das elites no poder. A preocupação verificada na posse de Plínio Coelho ${ }^{62}$ em seu primeiro mandato talvez possa lançar luzes sobre o desfecho do segundo.

57 SANTOS, op. cit., 1997, p. 142.

58 GARCIA, Etelvina. op. cit., 2012, p. 101-102.

59 A Tarde, Manaus, p. 3, 29 jan. 1955.

60 A Tarde, Manaus, p. 3, 29 jan. 1955.

61 Para Jorge Ferreira, a "institucionalização do projeto tenha sido a organização mais popular durante a experiência democrática pós-45, tornando-se, em 1964, a maior agremiação no espectro político do país". FERREIRA, Jorge Luiz. O nome e a coisa: o populismo na política brasileira. In: O populismo e sua história: debate e crítica. Rio de Janeiro: Civilização Brasileira, 2001, p. 79.

62 Para Márcio Souza, esse era o representante do populismo na política local, que viria a reorganizar, após o Estado Novo, mesmo que temporariamente, a administração do Estado. (SOUZA, 1978, p.149). 
A eleição de 1954 representou um passo gigantesco para a consolidação eleitoral do PTB amazonense que, além de ter logrado o êxito de eleger o governador, conquistou as duas cadeiras no Senado Federal, com Leopoldo Cunha Mello e Antovilla Rodrigues Mourão Vieira, quatro dos sete deputados federais (Josué Cláudio de Souza, Alberico Antunes de Oliveira, Áureo Bringel de Melo e Antero Ferreira Riça Jr.) e onze deputados estaduais. ${ }^{63}$ Segundo Maria Celina D'Araújo, o antigo PTB foi o partido que mais cresceu eleitoralmente de 1945 até 1962 junto a uma crescente atuação na área sindical ${ }^{64}$ e, certamente, o PTB amazonense acompanhou esse crescimento, se consolidando no cenário político local.

Não pretendo aqui abordar o primeiro governo de Plínio Ramos Coelho uma vez que já me detive neste tema em outra ocasião. ${ }^{65}$ No entanto, gostaria de destacar algumas das disputas e embates ocorridos entre os anos de 1954 e 1958. Primeiramente, devemos ressaltar o grande embate protagonizado entre o novo governo e os partidários de Álvaro Maia que há muito ocupavam os principais postos da máquina pública. Com isso, ao mesmo tempo em que recorrentemente se referia à herança deixada pelo seu antecessor, que deixara uma "massa falida", começou uma operação limpeza, iniciando uma série de cortes no funcionalismo público com a finalidade de afastar do poder esses setores ligados a Álvaro Maia (os primos felizes), gerando grande insatisfação entre os opositores que se queixavam de perseguição política. Quanto a isso, em mensagem à Assembleia Legislativa, o governador afirmou que foi "obrigado a cortar na própria carne, exonerando centenas de servidores públicos". ${ }^{66}$

Em segundo lugar, a opção pelo desenvolvimento econômico a partir do crescimento da atividade industrial gerou um forte desgaste de Plínio junto às classes conservadoras e à elite tradicional amazonense. A crítica que fazia à insistência com a atividade extrativista desagradava as elites locais e pode ser compreendida sob dois aspectos: 1) o desenvolvimento dos setores urbanos mais propensos eleitoralmente ao trabalhismo; 2) enfraquecimento dos setores tradicionais já identificados anteriormente como aliados do PSD e do PSP. Nesse sentido, a opção pelo estímulo à industrialização como forma de recuperar a economia regional fica evidente nas mensagens do governador do estado à Assembleia Legislativa. Plínio Coelho demonstra nítido interesse em incentivar por meio de políticas públicas a instalação de estabelecimentos que poderiam receber "favores constitucionais conferidos às indústrias nascentes que acaso fossem instaladas no estado, em convite, destarte, aos capitais nacionais e estrangeiros que aqui desejassem [...] imprimir novos rumos à nossa economia". ${ }^{67}$

63 Os deputados estaduais eleitos pelo PTB em 1954 foram: Antônio Vital de Mendonça, Arthur Virgílio Filho, Augusto Paes Barreto, Edson Stanislau de Miranda, João de Brito Albuquerque Veiga, Joel Ferreira da Silva, José Henrique de Souza F. ${ }^{\circ}$, Lúcio de Siqueira Cavalcanti, Oséas de Souza Martins, Raimundo Brasil Barbosa Ferreira e Xenofonte Antony.

64 D'ARAÚJO, Maria Celina. Sindicatos, carisma e poder: o PTB de 1945-65. Rio de Janeiro: FGV, 1996, p. 15.

65 QUEIRÓs, César Augusto Bubolz. O Trabalhismo de Plínio Ramos Coelho e o golpe de 1964 no Amazonas. Revista Mundos do Trabalho, Florianópolis, v. 8, n. 15, p. 49-65, 2016.

66 Mensagem do Governador Plínio Ramos Coelho à Assembleia Legislativa, 15 de março de 1955 , p. 11.

67 Mensagem do Governador Plínio Ramos Coelho à Assembleia Legislativa, 23 de março de 1958, p. 8. 
Ao analisar o primeiro governo de Plínio Coelho, Gilberto Mestrinho afirmou que:

Havia uma rejeição muito grande ao governador [Plínio Ramos Coelho]. Depois da eleição do Plínio, ele iniciou um movimento contra o status quo da época e esse status quo da época era liderado por uma oligarquia dominante constituída de coronéis. Esse grupo era que dominava o Amazonas e nós derrubamos tudo isso com o trabalhismo. ${ }^{68}$

Em terceiro lugar, podemos destacar a disputa estabelecida com a nova direção da Associação Comercial do Amazonas (ACA), importante associação comercial do estado. Tal desentendimento ocorreu quando, em abril de 1956, foi eleito para a presidência da ACA Isaac Benaion Sabbá, ${ }^{69}$ um membro da UDN, o que resultou no início de uma crise entre a entidade e o Executivo estadual. Não admitindo que a presidência de uma associação tão importante caísse nas mãos da oposição, Coelho inicia uma série de retaliações contra a entidade, retirando subsídios de que gozava a associação, o que a obrigou a extinguir vários serviços prestados para adequar as despesas aos recursos. O governador decretou ainda, por meio da Secretaria de Finanças, o congelamento dos repasses de meio por cento sobre os produtos exportados. ${ }^{70}$ Essa queda de braços entre a ACA e o Executivo estadual criou enormes dificuldades políticas ao governo de Plínio. O periódico Diário da Tarde destacava esse embate ao afirmar que

a cidade está dividida. $\mathrm{O}$ caso da Associação Comercial criou dois campos. Um defende o Sr. Secretário de Finanças e o outro a existência da ACA. E preparem-se ambos para ver o desenrolar da batalha e aclamar o vencedor. ${ }^{71}$

Por fim, observamos que, mesmo tendo a maior bancada na Assembleia, o governador enfrentava grandes dificuldades políticas. O jornal Diário da Tarde constatava, em março de 1956, que o "Legislativo encontra-se dividido em dois blocos, com a mesma força e com a mesma expressão numérica, isso é, 15 deputados da situação e 15 da oposição". ${ }^{72}$ Ademais, a situação econômica do estado era bastante delicada e a população enfrentava sérios problemas de abastecimento de água, energia elétrica e gêneros alimentícios e os atrasos nos pagamentos dos salários do funcionalismo público eram recorrentes.

Se o governador enfrentava embates com a oposição política, com a Associação Comercial do Amazonas e com o Legislativo estadual, com a aproximação das eleições de 1958 surgiria mais uma frente de batalha. E essa nova frente seria dentro das próprias fileiras do PTB. Plínio Coelho havia firmado um acordo com o senador Vivaldo Lima F. ${ }^{\circ}$ para que

68 Entrevista de Gilberto Mestrinho. Apud, TORRES, Iraíldes Caldas. A arquitetura do poder: memória de Gilberto Mestrinho. Manaus: EDUA, 2009. p. 74.

69 Isaac Benaion Sabbá foi eleito presidente da Associação Comercial do Amazonas para o biênio 1957/1958, tendo Ermínio Fernandes Barbosa e José Ribeiro Soares como primeiro e segundo vice-presidentes, respectivamente. FERREIRA FILHO, Cosme. Associação Comercial do Amazonas: Primeiro Centenário da ACA. Ed.: Umberto Calderaro, 1971, p. 156.

70 ROLIM, Amarildo Rodrigues. Do sonho à realidade: os ideais trabalhistas de desenvolvimento econômico para o Amazonas nas décadas de 50 e 60 do século XX. Dissertação (Mestrado em Sociedade e Cultura na Amazônia) - Instituto de Ciências Humanas e Letras, Universidade Federal do Amazonas, Manaus, 2006, p. 113.

71 Diário da Tarde, Manaus, p. 3, 13 abr. 1956.

72 Diário da Tarde, Manaus, p. 3, 13 abr. 1956. 
este fosse o candidato à sucessão no Executivo estadual. Entretanto, a direção do partido acabou indicando o nome de Gilberto Mestrinho, que justamente começara sua carreira política ao ser indicado por Plínio Coelho para assumir a prefeitura de Manaus em setembro de 1956 e que, ao deixar o cargo, ocupara o cargo de secretário de Economia e Finanças no governo estadual. Segundo Gomes, o esforço de reestruturação partidária necessário para consolidar o PTB nos estados e municípios após a morte de Vargas trouxe consigo lutas entre lideranças políticas pelo controle nacional e/ou estadual da organização, disputas que estavam profundamente imbricadas com lutas simbólicas pelo controle das formas de representação do partido. Nesse sentido, não é casual que esse seja um período de proliferação e de competição entre lideranças que disputam a hegemonia dentro da máquina partidária. ${ }^{73}$ No Amazonas, a indicação do candidato que disputaria a sucessão de Plínio Ramos Coelho ao governo do estado desencadeou disputas intrapartidárias entre suas principais lideranças. $\mathrm{O}$ Diário da Tarde assim noticiava a escolha do Partido Trabalhista Brasileiro para a sucessão ao Executivo:

Plínio Ramos Coelho, em reunião com as principais lideranças do partido, elas manifestam a indicação do nome do professor Gilberto Mestrinho de Medeiros Raposo para governo, apesar do acordo entre Plínio Ramos Coelho e o senador Vivaldo Lima. ${ }^{74}$

Tal situação evidencia a contestação da autoridade política daquela que se tornara a principal liderança partidária do estado e pode indicar um desgaste do então governador que não conseguira fazer o seu candidato à sucessão. Plínio Coelho era, além de governador, o presidente do PTB e iniciara manobras políticas para lançar o nome de Vivaldo Lima. No entanto, passou a ser pressionado pelos próprios correligionários que faziam críticas a seu governo e que o consideravam como um "traidor das causas trabalhistas". Diante dessa crescente insatisfação dentro do próprio partido, na convenção do partido, Plínio Coelho lançou o nome de Gilberto Mestrinho que, em virtude de sua ativa participação nas atividades partidárias e do governo, vinha ganhando crescente espaço no partido. Na convenção, Mestrinho ganhou 47 votos dos 50 possíveis. ${ }^{75}$ Vivaldo Lima F. ${ }^{\circ}$ concorreria a uma vaga ao Senado.

Durante a campanha de Gilberto Mestrinho para o governo do estado, observamos diversas referências da oposição, vinculada à Frente Democrática Popular (FDP), ${ }^{76}$ à figura de Plínio Coelho, chamado pejorativamente de 'Plínio, o louco', ou de 'Plínio, o propineiro'. ${ }^{77}$

Embora tenha perdido a disputa pela indicação de seu sucessor, o legado e a imagem de Plínio Coelho serão utilizados recorrentemente durante a campanha de Mestrinho, que se colocava como continuador da "obra de Plínio, o carinho de Plínio para com a 'gentinha". 78

ROLIM, op. cit., 2006, p. 137.

Diário da Tarde, Manaus, p. 1, 14 jan. 1957.

TORRES, op. cit., p. 76.

76 A Frente Democrática Popular era composta por PSP, PSD, UDN, PDC, PRP, tendo como candidato ao Palácio Rio Negro Paulo Pinto Nery e ao Senado Álvaro Botelho Maia.

77 Diário da Tarde, Manaus, 14 jan. 1957.

78 Jornal do Commercio, Manaus, p. 3, 9 ago. 1958. 
Torna-se interessante observar que o PTB assumira a alcunha de "partido da gentinha", utilizada para depreciá-lo. Para D’Araújo, a prática governista associada a uma crescente atuação na área sindical rendeu ao partido "certa plasticidade, permitindo identificá-lo como um 'partido dos pobres no poder"' ${ }^{79}$ Quanto às críticas feitas ao governo do PTB, Mestrinho destacava que "desde que Plínio Coelho assumiu o governo não mais houve, não há e nem haverá, na administração pública do Amazonas, lugar e oportunidade para safadezas" . ${ }^{80}$

Do mesmo modo, a figura de Getúlio Vargas era constantemente invocada, sendo realizados comícios em sua memória.

Verão os trabalhadores de riso estampado nas faces, verão crianças felizes, sentirão corações em festa vivando Vargas, vivando Plínio, vivando Gilberto, vivando o Vivaldo, vivando o 'partido da gentinha', vivando o glorioso Partido Trabalhista Brasileiro. ${ }^{81}$

Essa associação com a figura de Vargas em torno do partido está relacionada à construção de um imaginário popular por meio do qual tal ligação é transformada muitas vezes em argumento de autoridade autoexplicativo onde o

personalismo, doutrina e ideologia, associados a bom desempenho nas urnas e a facilidades junto aos sindicatos e ao poder, fizeram do velho partido um caso excepcional de sucesso. Por trás desse sucesso sempre esteve um certo tom heroico atribuído ao fato de que, a exemplo de Vargas, elegia o trabalhador como interlocutor e como alvo de suas ações. ${ }^{82}$

Tal associação inevitavelmente remete à presença de uma personalidade dominante, um líder carismático, no processo de fundação do partido, promovendo o estabelecimento de uma identidade entre sua imagem pessoal e a do partido. Ao mesmo tempo em que confere legitimidade e autoridade ao discurso político, a referência a Vargas alude a um aparato ideológico e uma base social específica, buscando potencializar o carisma pessoal de quem empresta autoridade e legitimidade ao discurso partidário. Nesse sentido, a gênese do PTB é indissociável da figura de Getúlio Vargas, o líder que estabeleceu sua base social e definiu seus objetivos. Percebendo a apropriação da figura de Vargas pelos discursos trabalhistas, a oposição - organizada na Frente Democrática Popular ${ }^{83}$ - criticava "a falta de escrúpulos na exploração contínua da respeitável memória de Getúlio Vargas nos comícios políticos e na imprensa onde, quais hienas famintas, eles revolvem o seu túmulo, buscando refúgio para o merecido repúdio que nesta oportunidade Ihes devota o povo amazonense". ${ }^{84}$

Nas eleições de 1958, o PTB volta a ter um resultado bastante significativo e consolida sua posição no cenário político do estado. Em 1958, o PTB conquistou o segundo mandato consecutivo no Executivo amazonense, com a vitória de Gilberto Raposo Mestrinho sobre o candidato da UDN Paulo Pinto Nery; elegeu o senador Vivaldo Lima F. ${ }^{\circ}$, que derrotou

79 D’ARAÚJO, op. cit., 1996, p. 15.

80 Jornal do Commercio, Manaus, p. 3, 9 ago. 1958.

81 Jornal do Commercio, Manaus, p. 3, 9 ago. 1958.

82 D'ARAÚJO, op. cit., 1996, p. 15.

83 A Frente Democrática Popular era composta por PSP, PSD, UDN, PDC, PRP, tendo como candidato ao Palácio Rio Negro Paulo Pinto Nery e ao Senado Álvaro Botelho Maia.

84 A Crítica, Manaus, p. 1, 20 maio 1958. 
nas urnas o poderoso Álvaro Maia; três deputados federais (Arthur Virgílio F. ${ }^{\circ}$, João Veiga e Adalberto Vale), além de dez deputados estaduais. ${ }^{85}$ No entanto, a vitória de Gilberto Mestrinho - em uma eleição marcada por denúncias de fraude eleitoral ${ }^{86}$ - foi por uma margem apertada de votos e Mestrinho foi derrotado no interior, onde a influência das oligarquias, dos seringalistas e coronéis era maior e a rejeição a Plínio Coelho era grande: no interior, Paulo Nery teve 17.926 votos contra 14.159 de Mestrinho, que venceu aquele pleito por uma diferença de 1.152 votos (37.323 contra 36.171$)$. Some-se a isso o fato de que o PTB ainda não se organizara de forma efetiva em muitos municípios do interior, onde a influência do PSD era muito grande.

Segundo Iraíldes Torres, até meados da década de 1950, o partido constituía apenas a terceira força política do estado - atrás de PSD e UDN, que contavam com ampla maioria nos legislativos federal e estadual. ${ }^{87} \mathrm{~A}$ consolidação do PTB como o principal partido do estado e o surgimento de novas alianças resulta no acirramento das disputas internas no partido, opondo diametralmente as duas principais lideranças trabalhistas: Plínio Ramos Coelho e Gilberto Raposo Mestrinho. ${ }^{88}$

No governo de Mestrinho, a consolidação do trabalhismo no Amazonas se intensifica, ${ }^{89}$ com o fortalecimento das relações do governo com as lideranças sindicais locais, principalmente dos estivadores. As várias greves ocorridas em seu governo - como a dos estivadores, que paralisaram o porto de Manaus, ou a dos motoristas e choferes, em 1961 -, a proteção que as polícias civil e militar dispensavam aos cordões grevistas e o apoio dado pelo próprio Mestrinho aos movimentos - como no episódio em que Mestrinho passou aplaudindo a paralisação dos motoristas na avenida Eduardo Ribeiro - teriam causado desconforto às elites.

Contudo, as rivalidades dentro do partido, que haviam sido iniciadas na disputa entre Mestrinho e Plínio pela indicação do candidato à sucessão ao governo do estado, irão se incendiar por ocasião da campanha presidencial de 1960. Mesmo com a nomeação para a prefeitura de Manaus, Plínio Ramos Coelho apoiou a dobradinha Jânio-Jango, enquanto Gilberto Mestrinho seguiu as orientações da cúpula do partido e apoiou a candidatura de Henrique Lott. Essa divisão acarretou um rompimento pessoal entre eles e gerou intensas disputas políticas e troca de acusações. Gilberto Mestrinho, que assumira a organização da

85 Os deputados estaduais eleitos pelo PTB em 1958 foram os seguintes: Anfremon D'Amazonas Monteiro, Arlindo Augusto dos Santos Porto, Belarmino Ferreira Lins Filho, Darcy Augusto Michelles, Austregésilo Mendes, Francisco da Gama Silva, Josué Cláudio de Souza, Manuel Alexandre Filho, Renato de Sousa Pinto e Stênio Neves.

86 "Havia fraude eleitoral de todos os tipos, desde a votação de eleitores já mortos até abuso do poder econômico e uso da máquina estatal para facilitar a campanha dos trabalhistas". A Tarde, Manaus, p. 3, 30 out. 1958. O apelido de Mestrinho - Boto Tucuxi - faz alusão às peripécias do boto que "emprenha as urnas". TORRES, op. cit., p. 103

87 TORRES, op. cit., p. 83.

88 QUEIRÓS, César Augusto Bubolz. O Trabalhismo de Plínio Ramos Coelho e o golpe de 1964 no Amazonas. Revista Mundos do Trabalho, Florianópolis, v. 8, n. 15, p. 49-65, 2016.

89 Segundo Alzira Vargas, o objetivo inicial de ser um anteparo para os operários teria falhado principalmente porque "o PTB foi formado na base de homens e não de ideias, como, aliás, quase todos os partidos daquela época. Os homens se juntavam em torno de alguém que sabiam que ia dirigi-los [...] Do ponto de vista doutrinário, não havia propriamente uma convicção trabalhista”. D’ARAÚJO, op. cit., 1996, p. 22. 
campanha pró-Lott no Amazonas, repetidamente argumentava que renunciaria ao cargo de governador do estado caso seu candidato fosse derrotado.

Para deixar claro seu apoio à candidatura de Jânio Quadros à Presidência da República, Plínio Ramos Coelho utilizava o periódico O Trabalhista ${ }^{90}$ fazendo forte campanha em favor da eleição da dupla Jan-Jan. Em documento intitulado Nona Carta aos Trabalhadores, o ex-governador afirmava acreditar na vitória de Jânio Quadros e João Goulart por considerar que o candidato apoiado pelo PTB, Henrique Lott, era um dos generais que exigira a renúncia de Getúlio Vargas em 1954. Ademais, o periódico imputava a Jânio Quadros um nacionalismo que estaria ausente no candidato Henrique Lott, atribuindo a Jânio Quadros o papel de continuador da obra de Getúlio Vargas.

Com a intensificação das disputas em torno dos apoios às candidaturas de Lott e Jânio, o governador Gilberto Mestrinho demitiu Plínio Ramos Coelho da prefeitura de Manaus. A demissão de Plínio Coelho da prefeitura de Manaus evidenciava as disputas entre os trabalhistas e poderia repercutir negativamente sobre a candidatura de Henrique Lott no estado. Segundo o deputado Simão Fares Abnaber,

A situação política no Amazonas apresentava-se favorável ao marechal Lott até há quinze dias, mas a demissão do prefeito Plínio Coelho pelo governador Gilberto Mestrinho, que queria impor-Ihe a candidatura do ex-ministro da Guerra, desencadeou uma onda de indignação em todo o estado, com reflexos positivos para o nome do sr. Jânio Quadros, cuja penetração passou a ser avassaladora no Amazonas. ${ }^{91}$

As disputas entre Mestrinho e Plínio tornavam-se cada vez mais agudas. Em manifesto do movimento Lott-Jango, Plínio Coelho era apresentado como o inimigo número um do funcionalismo amazonense - em virtude dos constantes atrasos salariais em seu governo enquanto Gilberto Mestrinho era o grande defensor do funcionalismo público. O manifesto salientava que, para prestigiar Mestrinho, os servidores deveriam lutar pela vitória de Lott, já que deveriam lembrar-se que foram "miseravelmente esbugalhados em seus legítimos direitos graças à arbitrariedade de um mau governante como o Dr. Pata Choca (Plínio Ramos)". Além de ser chamado de Plínio Pata Choca, o ex-governador era tratado como o "doidinho que desgovernava o Estado". ${ }^{92}$ Devemos reforçar que Gilberto Mestrinho entrou na vida política pelas mãos de Plínio Coelho ao ser indicado para ocupar o cargo de prefeito de Manaus em 1956 - justamente o cargo para o qual indicou e demitiu Plínio em 1960. Embora tenhamos observado que as divergências entre mentor e pupilo se iniciaram justamente no episódio em que as principais lideranças do partido manifestaram a indicação do nome de Mestrinho para concorrer ao governo em 1958, apesar do acordo entre Plínio Ramos Coelho e o senador Vivaldo Lima, o Jornal do Commercio, claramente identificado com Gilberto Mestrinho, afirma

90 O Trabalhista era um periódico vinculado à rede Difusão, de propriedade de Plínio Ramos Coelho. Foi fechado pelo interventor Arthur Cesar Ferreira Reis após o golpe civil-militar de 1964. O Trabalhista, Manaus, p. 3, 24 ago. 1960.

91 O Trabalhista, Manaus, p. 3, 24 ago. 1960.

92 Jornal do Commercio, Manaus, p. 1, 1 out. 1960. 
que as desavenças entre ambos começariam no governo de Mestrinho, pois Plínio só queria que Mestrinho agisse com sua licença, "queria que o prof. Gilberto Mestrinho fosse o seu boneco". ${ }^{93}$

Com o agravamento das tensões entre os dois grupos, Plínio passa a denunciar que seus amigos e seguidores vinham sendo perseguidos por Mestrinho, sendo demitidos e transferidos sumariamente. Uma nota publicada no jornal O Trabalhista informa que os moradores do bairro Parque 10 entregaram um manifesto de apoio a Plínio Coelho e protestaram contra o que consideraram uma vingança do governador Gilberto Mestrinho ao demitir o delegado Mário Viana, aliado de Plínio. ${ }^{94}$

Às vésperas das eleições, a capa do Jornal do Commercio estava tomada por matérias alusivas à candidatura de Lott. Álvaro Maia e Gilberto Mestrinho se empenharam pessoalmente nessa candidatura: PSD e os aliados de Mestrinho do PTB dividiram o palanque e empenharam esforços conjuntos para garantir a vitória de Lott no estado. A aliança entre Lott e Jango representaria a união entre a "orientação trabalhista de Getúlio Vargas e a desenvolvimentista de Kubitschek". ${ }^{95}$ Entre mensagens alusivas à candidatura do marechal Lott e a consagração dos feitos do governo JK, esse periódico mostrava-se claramente favorável à candidatura do candidato pessedista.

Jânio Quadros venceu as eleições presidenciais de outubro de 1960, tendo recebido $48 \%$ dos votos do eleitorado, contra $32 \%$ dados a Henrique Teixeira Lott e $20 \%$ a Ademar de Barros. Tomou posse, juntamente com João Goulart, no dia 31 de janeiro de 1961. No entanto, no estado do Amazonas, a vitória foi de Lott. ${ }^{96}$ Apesar dos esforços de Plínio Coelho, seu candidato recebeu apenas 23.812, contra 32.324 do candidato pessedista. Decerto, o candidato do PSD contou com o apoio de importantes lideranças políticas locais - como Gilberto Mestrinho e Álvaro Maia -, com o claro apoio do maior jornal em circulação no Amazonas - o Jornal do Commercio - e com a utilização da máquina pública, instrumentalizada a favor de Henrique Lott pelo governador Gilberto Mestrinho. O afastamento entre o grupo de Mestrinho e o de Plínio atingiu seu auge e, em outubro de 1960, Plínio se encontrava enfraquecido dentro do PTB e sequer fazia parte do Diretório do Partido Trabalhista Brasileiro no Amazonas. ${ }^{97} \mathrm{O}$ ex-governador considerava que um apoio a Henrique Lott, do PSD, poderia resultar no fortalecimento de seus adversários no estado. No entanto, tal posição ocasionou um relativo isolamento político e fez com que que muitas lideranças trabalhistas o acusassem de traidor do partido, sobretudo em um quadro de franco crescimento da influência política de Mestrinho. Em carta publicada no Diário da Tarde e endereçada ao então candidato Plínio Coelho, essa traição era demonstrada da seguinte forma: "O sr. traiu, compadre, o nosso

93 Jornal do Commercio, Manaus, p. 1, 2 out. 1960.

94 O Trabalhista, Manaus, p. 3, 24 ago. 1960.

95 Jornal do Commercio, Manaus, p. 1, 1 out. 1960.

96 Além do Amazonas, Henrique Lott obteve vitória nos seguintes estados: Amapá, Distrito Federal, Goiás, Maranhão, Piauí, Rio Branco, Rio de Janeiro e Sergipe.

97 Naquela ocasião, o diretório era formado por Gilberto Mestrinho, Leopoldo Cunha Melo, Vivaldo Lima, Arthur Virgílio do Carmo, Josué Cláudio de Souza, Otávio Teixeira Moraes da Câmara e João de Brito Albuquerque Veiga Filho (Jornal do Commercio, Manaus, 2 out. 1960). 
PTB, abandonando os candidatos nacionais, Lott e Jango, para apoiar os candidatos da UDN. Está provada, não é compadre, essa traição?". ${ }^{98}$ O crescimento eleitoral do partido trazia consigo disputas internas e rivalidades que colocavam em lados opostos as suas principais lideranças no estado.

Com a aproximação das eleições de 1962 para o governo do estado do Amazonas e com a possibilidade de firmar um terceiro mandato trabalhista, a reaproximação entre Mestrinho e Plínio era extremamente necessária para a consolidação do PTB no estado. Não havia outro candidato que pudesse ter o peso eleitoral e a popularidade do ex-governador. Ao mesmo tempo, seria improvável um sucesso eleitoral sem o apoio de Gilberto Mestrinho. Assim, o então deputado federal Arthur Virgílio Filho ficou responsável pelo movimento de pacificação do Amazonas e pela reaproximação entre os dois desafetos políticos. Arthur Virgílio havia sido colega de Plínio Ramos Coelho no curso de Direito na Universidade de Manaus e, posteriormente, ambos foram eleitos para a Assembleia Legislativa na mesma legislatura. Sobre esse contexto, Mestrinho afirma que

O Plínio tinha me botado na política e eu admirava muito ele, mas ele tinha muito ciúme e com isso ele ficou sozinho. Um dia, o Arthur Virgílio do Carmo Ribeiro Filho, que era deputado federal, me procurou e disse-me: olha, Gilberto, não briga com o Plínio. Mas ele era muito difícil. ${ }^{99}$

Assim, a despeito das fissuras que a disputa presidencial provocou na relação entre Plínio e Mestrinho, Gilberto Mestrinho manifestou seu apoio à candidatura de Plínio Coelho para o governo do estado do Amazonas não sem alfinetar o antigo padrinho político e desafeto: "Depois de derrotá-lo duas vezes [...] vou lançar a candidatura do sr. Plínio Coelho à minha sucessão, na convenção do PTB". ${ }^{100}$

Às vésperas da eleição, Arthur Virgílio manifestava a certeza de que Plínio Coelho seria reconduzido pela segunda vez ao Palácio Rio Negro, com "larga margem de votos na capital e no interior". Segundo ele,

O PTB, junto com seus tradicionais aliados - PSD e PSB -, demonstrou em dois pleitos contar com o apoio da maioria do eleitorado amazonense. Em 1954 e em 1958, vencemos uma poderosa e coesa coligação oposicionista. No pleito de outubro, a nossa posição ainda é mais favorável. O PTB, unificado, conta também com o apoio dos mais prestigiosos elementos do PSD, da UDN, do PSP, do PDC e do PL, que integraram a oposição naquelas eleições. Foram conosco, ao lado de Gilberto Mestrinho e de Plínio Coelho, entre outros. Se a vitória em 1954 e em 1958 nos sorriu, quando apenas as forças trabalhistas enfrentaram os adversários, só muita ingenuidade poderá pensar que perderemos agora, quando fortalecem nossa luta os prestigiosos políticos que acabei de citar, em cuja relação inclui valorosos deputados que passaram a apoiar o ilustre governador Gilberto Mestrinho desde 1959, como Sérgio Pessoa Neto, Augusto Montenegro, Tércio Araújo da Silva, Dédimo Soares e Isaac de Oliveira Sabbá. ${ }^{101}$

98 Diário da Tarde, Manaus, p. 4, 27 ago. 1962.

99 Entrevista de Gilberto Mestrinho. In: TORRES, op. cit., p. 120.

100 Estado de São Paulo, São Paulo, 28 abr. 1962.

101 CASTRO, Mário Adolfo. Arthur Virgílio Filho: perfis parlamentares. Brasília: Edições Câmara, 2011 , p. 60. 
No entanto, a despeito do otimismo de Arthur Virgílio com uma vitória trabalhista no pleito, o periódico Diário da Tarde dava como certa a vitória eleitoral de Paulo Nery, pois "o povo do interior já considera Paulo Nery governador eleito do Amazonas". ${ }^{102}$ De fato, foi uma disputa concorrida. Os aliados do alvarismo se empenharam em retomar o poder no estado e lançaram a candidatura de Paulo Nery, do PSP, em uma aliança com UDN e PSD. Contudo, o resultado da eleição apontou para a consolidação do prestígio do PTB no estado: Plínio Ramos Coelho ${ }^{103}$ foi eleito para o terceiro mandato do PTB no Amazonas, fazendo 54.800 votos, contra 42.878 de Paulo Pinto Nery. O partido conseguiu eleger seus dois senadores: Antovila Mourão Vieira e Arthur Virgílio F.․ Álvaro Maia novamente fora derrotado em uma eleição, o que confirma a queda gigantesca em seu prestígio. Dos sete deputados federais eleitos, o PTB elegeu três: Almino Monteiro Álvares Afonso, João Veiga e José Raimundo Esteves. No entanto, verifica-se uma queda na representação trabalhista na Assembleia Legislativa: de dez deputados em 1958, só foi possível eleger seis. ${ }^{104}$ Nessa eleição, Gilberto Mestrinho se filiou ao PST e se elegeu deputado federal pelo território de Roraima.

A vitória eleitoral de Plínio Ramos Coelho representou a consolidação da hegemonia trabalhista no estado do Amazonas uma vez que, com aquela vitória, o PTB enfileirava três mandatos consecutivos e (aparentemente) fragilizava a oposição alvarista. No entanto, ao longo de seu segundo mandato (terceiro mandato do PTB), Plínio Ramos Coelho enfrentou forte oposição de diversos setores a seu governo e, com a deflagração do golpe civil-militar de 1964, sofreu a deposição em junho daquele ano, passando a enfrentar forte perseguição política do governador indicado, Arthur Cézar Ferreira Reis. ${ }^{105}$ Lideranças trabalhistas do estado sofreram cassações e perseguições, como nos casos do deputado federal Almino Afonso, ${ }^{106}$ do ex-governador Gilberto Mestrinho, do deputado estadual Arlindo Porto e dos vereadores Nathanael Rodrigues e Manoel Rodrigues da Silva, ex-dirigente do Sindicato dos Estivadores, ${ }^{107}$ e seu suplente Othon Mendes. ${ }^{108}$ A partir daí, o Amazonas - assim como o restante do país - mergulharia em um cenário de autoritarismo e repressão que perduraria por longos anos.

102 Diário da Tarde, Manaus, p. 3, 23 ago. 1962.

103 Sobre o segundo governo de Plínio Ramos Coelho, ver: QUEIRÓS, César Augusto Bubolz. 'Papagaio que está trocando as penas não fala': autoritarismo e disputas políticas no Amazonas no contexto do golpe de 1964. Revista de História da Unisinos, São Leopoldo, v. 23, n. 1, p. 73-83, 2019.

104 Os deputados estaduais eleitos foram Arlindo Porto, Augusto Montenegro, Darcy Augusto Michilles, Gregório Dias, Bernardo Cabral e Renato de Souza Pinto.

105 Já analisamos o segundo governo de Plínio Ramos Coelho e o golpe de 1964 no Amazonas em: QUEIRÓS, César Augusto Bubolz. 'Papagaio que está trocando as penas não fala': autoritarismo e disputas políticas no Amazonas no contexto do golpe de 1964. Revista de História da Unisinos, São Leopoldo, v. 23, n. 1, p. 7383, 2019.

106 Almino Afonso foi o candidato que obteve a maior votação para a Câmara dos Deputados pelo Amazonas, reelegendo-se com 13.870 votos e exercendo a função de líder do PTB na Câmara. Foi ministro do Trabalho e da Previdência Social de João Goulart. Estava na primeira lista de cidadãos que tiveram mandatos e direitos políticos cassados em decorrência do Ato Institucional nº 1, em 10 de abril de 1964.

107 Em abril, o Sindicato dos Estivadores de Manaus sofreu uma intervenção militar. Jornal do Commercio, Manaus, p. 1, 28 abr. 1964.

108 Jornal do Commercio, Manaus, p. 8, 5 maio 1964. 


\section{Considerações Finais}

Ao LONGO DESTE ARTIGO, buscamos compreender o processo de formação do Partido Trabalhista Brasileiro (PTB) no Amazonas e a consolidação da hegemonia trabalhista entre as décadas de 1950 e 1960, analisando as disputas políticas que emergem após o processo de redemocratização no pós-45 e o enfrentamento entre o trabalhismo - em emergência - e o alvarismo - consolidado pela longa permanência de Álvaro Maia como governador constitucional e interventor no estado e pela utilização daquela estrutura política para o fortalecimento do PSD. O crescimento do PTB no estado se deu, sobretudo, a partir da eleição do advogado Plínio Ramos Coelho para o governo do estado do Amazonas em 1954 que, contando com o apoio de Getúlio Vargas no final da década de 40 e início da década seguinte, inaugurou um período de hegemonia trabalhista que teve continuidade com a eleição de Gilberto Mestrinho (1958) e, novamente, Plínio Coelho (1962), tendo se estendido até sua deposição, em junho de $1964 .{ }^{109}$ A partir da eleição de Plínio Coelho, em 1954, o PTB logrou excelentes resultados eleitorais no estado, vencendo por três vezes consecutivas a eleição para o governo do estado (1954, 1958 e 1962), conquistando ao longo desses anos uma forte presença tanto no Legislativo estadual quanto no federal. $O$ estudo do processo de consolidação do trabalhismo no estado do Amazonas e a trajetória de suas principais lideranças pode lançar luzes sobre o cenário político recente uma vez que a hegemonia do PTB - alcançada ao longo das décadas de 1950 e 1960 - pode ser verificada até os dias atuais, com a perpetuação de herdeiros políticos dessas lideranças no poder no estado. Desde o retorno das eleições governamentais, em 1982, o Amazonas tem sido governado por um grupo pequeno e relativamente fechado de políticos que ora se aliam, ora se opõem, tendo como patriarca o ex-governador Gilberto Mestrinho. Entre 1983 e 2010, o estado do Amazonas elegeu apenas três governadores, que se alternaram no poder: Gilberto Mestrinho, Amazonino Mendes e Eduardo Braga. Devemos salientar que Amazonino Mendes entrou na vida política pelas mãos de Gilberto Mestrinho, que, em 1983, o indicou para assumir a prefeitura de Manaus. Eduardo Braga foi candidato a vice-prefeito de Manaus na chapa de Amazonino Mendes nas eleições de 1993. Desde 1982, o Amazonas teve os seguintes governadores: Gilberto Mestrinho (PMDB/1983-1987), Amazonino Mendes (PDC/1987-1990), Gilberto Mestrinho (PMDB/19911995), Amazonino Mendes (PFL/1995-1999), Amazonino Mendes (PFL/1999-2003), Eduardo Braga (PPS/2003-2007), Eduardo Braga (PMDB/2007-2010). Em 2017, Amazonino Mendes voltou a ser eleito para o governo do estado do Amazonas em um pleito suplementar ocorrido após o Tribunal Superior Eleitoral (TSE) ter cassado a chapa que elegeu o governador José Melo.

Recebido em: 21/03/2020

Aprovado em: 16/04/2020

109 QUEIRÓS, César Augusto Bubolz. O Trabalhismo de Plínio Ramos Coelho e o golpe de 1964 no Amazonas. Revista Mundos do Trabalho, Florianópolis, v. 8, n. 15, p. 49-65, 2016. 